\title{
PROTECTION OF PROPERTY RIGHTS IN THE CONVENTION FOR THE PROTECTION OF HUMAN RIGHTS AND FUNDAMENTAL FREEDOMS AND THE PRACTICE OF THE ECTHR
}

\section{Kizlova O. S.}

\section{INTRODUCTION}

It is well known that the fundamental ownership right in the sphere of business is the property right. Property right is the right of a person to a thing (property), which he performs in accordance with the law of his own will, regardless of the will of other persons (Article 316 of the Civil Code of Ukraine). The basis of any property is the economic relations of appropriation created in the process of social production of tangible goods (natural resources, means and products of productive activity, etc.), through an appropriate socio-economic system, which expresses the attitude of some persons to these tangible goods as "their", and others as "someone else's". Therefore, the first ones acquire the power of the "owner" of the property, the second ones- acquire the obligation to refrain from encroachment on him and to create obstacles to the "owner" in the dominance of this property. Property is a public relation between people about aught whose behavior is volitional. However, the functioning of this attitude and the behavior of its participants requires the necessary legal regulation.

In the context of the above subject of guarantee of property rights in accordance with Article 1 of the First Protocol to the Convention for the Protection of Human Rights and Fundamental Freedoms, in addition to this Article of the First Protocol, are also guaranteed the right to a fair trial (Article 6), the right to an effective remedy (Article 13), and the prohibition of discrimination (Article 14), the prohibition of abuse of rights (Article 17). The first Protocol defines the boundaries of international legal regulation of property rights issues. Legal regulation of property protection is a prerogative of the internal law of States. At the present stage of development, the legal ownership regime is changing significantly. This process is objectively caused by the need of the economy and at the same time the need to strengthen social regulation and fulfill the social functions of the state ${ }^{1}$.

${ }^{1}$ Civil and Commercial Law of Foreign States: a textbook: in 2 volumes / answer. ed. E.A. Vasiliev, A.S. Komarov. 4th ed., Rework and add. M.: International Relations, 2008. Vol. 1. P. 336. 560 p. 
According to Article 53 of the Convention, it is generally acknowledged that the protection mechanism provided for in the Convention is subsidiary to a mechanism which is required to be provided by a State party to the Convention at national level, since nothing in the Convention can be construed as restricting or invalidating any human rights and fundamental freedoms that may be recognized by the laws of any High Contracting Party or any other agreement to which it is a party ${ }^{2}$.

A protection system of property rights at the national level looks like mechanism that includes juridical tools, functional and institutional elements. Thus, institutional guarantees that are set out in Article 55 of the Constitution of Ukraine. Accordingly, universal protection of property rights is judicial protection. At the same time, everyone is guaranteed the right to challenge in court the decisions, actions or omissions of public authorities, local self-government bodies, officials, as well as to obtain compensation for material and moral damage caused by such illegal decisions, actions or inaction (Part 2 of Article 55, Article 56 of the Constitution of Ukraine). At the same time, there are two mechanisms of judicial protection. The first one acts as a national legal guarantee covering the system of national remedies (Articles 124, 125 of the Constitution of Ukraine). The second mechanism for judicial protection relates to international legal guarantees and is based on the recognition of the individual's rights and the creation of appropriate conditions for such protection to be applied to international judicial institutions, in particular the ECtHR.

\section{The essence of property rights in the civilistic doctrine}

Legal regulation of economic relations of ownership gives rise to the formation of property rights, by which the domination of the rightful person, which is the owner, over the things owned by him in the form of sole powers of ownership, use and disposal of them. Today, the thesis about the absolute nature of property rights is debatable and one that raises some questions among scholars. According to the researchers, Roman law did not know at all jus utendi et abutendi as the right of any use of a thing up to its destruction or a clear contradiction to the public interest ${ }^{3}$. Such an "absolute" characteristic of Roman private property law, according to F. Pichinelli, appeared in 1563, when the lawyer F. Hotomanus (Hotman) mistakenly interpreted the corresponding place of Corpus juris civils. Undoubtedly, due

2 Convention for the Protection of Human Rights and Fundamental Freedoms: International Document of 04 November 1950 // Official Journal of Ukraine. 1998. № 13. Art.

${ }^{3}$ Lazar J. Property in bourgeois legal theory: trans. with him. / J. Lazar. M.: Law. Lit., 1985. 182 p. P. 8. 
to the poor development of historical and legal science at the time, this assertion was accepted without a doubt.

Property relations constitute the economic foundation of any society, regardless of the degree and level of maturity. It confirms M.F. VladimirskyBudanov, who noted: "There is no doubt that rights of things and their highest expression - property rights - appear from the earliest times of human coexistence" ${ }^{\text {. }}$. History of economic and socio-political transformations shows that property relations are among the first to receive their doctrinal development and legal support.

At the same time, the property relations themselves with the change of political formations and the implementation of transformations in the sphere of economy are significantly complicated, which facilitates their more thorough study by the representatives of various sciences ${ }^{5}$.

In particular, in the Ukrainian civilistics, some prominent scientists, such as D.V. Bobrova, O.V. Dzera, O.M. Klimenko, N.S. Kuznetsova, V.M. Kossak, V.V. Luts, R.A. Maidanyk, I.V. Spasibo-Fateeva, E.O. Kharitonov, O.I. Kharitonova, J.M. Shevchenko., dedicated their aspects to the protection of property rights. In the context of exploring the practical aspects of applying the rules of Article 1 of the First Protocol and, accordingly, the ECtHR practices, there are certain developments among practitioners such as Z. Bortnovskaya, O. Davidchuk, D. Popovych, V. Milius, J. Romanyuk, P. Pushkar, O. Kot, P. Kulinich, A. Miroshnichenko, V. Kravchuk.

It is believed that the classical structure of property rights originates from Roman law. However, the authors of some recent studies argue that attributing to the Romans the interpretation of property rights as a triad of powers is an exaggeration, since no source of Roman law indicates such a construction of property. According to the concusions of V.A.Saveliev, the common identification of Roman dominium and proprietas is incorrect because they were used to denote different aspects of property relations ${ }^{6}$.

According to some scholars, the reference to the provisions of Roman law, under the influence of which allegedly formed modern ideas about property rights and the essence of economic relations of owners, seems exaggerated and somewhat Erroneous ${ }^{7}$. So, scientists refer to the work of

\footnotetext{
${ }^{4}$ Vladimirsky-Budanov M.F. Review of the history of Russian law / M.F. VladimirskyBudanov. 7th ed. Petrograd, Kiev: N.Y. Oglobin, 1915. 699 p. P. 507.

${ }^{5}$ Public Property: Problems of Theory and Practice: Monograph / ed. V.A. Ustimenko / NAS of Ukraine, Institute of Economic and Legal Research. Chernihiv: Desna Polygraph, 2014. 308 p. P. 7.

6 Savelyev V.A. Legal concept of property in Ancient Rome and modernity / V.A. Savelyev. The Soviet state and law. - Moscow: Nauka, 1990. No 8. P. 135-140. P. 139.

${ }^{7}$ Public Property: Problems of Theory and Practice: Monograph / ed. V.A. Ustimenko / NAS of Ukraine, Institute of Economic and Legal Research. Chernihiv: Desna Polygraph, 2014.
} 
J. Lazar "Ownership in bourgeois legal theory" 8 which, in their view, sheds light on certain aspects of the reception and interpretation of Roman law on property.

Roman lawyers simply could not come to a consensus and could not define a property right shared by all without exception. There is a growing recognition among scholars in the field of classical jurisprudence that the "passion for definitions", such characteristic of medieval canon law and later inherited by European rationalism, was deeply alien to Roman lawyers.

Roman law did not produce a "single" and "absolute" definition of property rights; instead, the institution of property rights, "divided" into separate powers, was well designed. Dominium meant full legitimate authority, proper domination of a certain bodily object, in which the legal and personal aspects were combined; it was acquired only in legitimate ways. Proprietas is a property right that is opposed to another property right - ususfructus - the right to use the thing and to receive income. The purpose of proprietas is to emphasize, not the aspect of ownership of a thing, but its belonging to a particular person; so there is nothing in common between property (proprietas) and ownership ${ }^{9}$.

According to the conclusion V.M. Smirin makes in his article on the property in Roman law, the absence of a conceptual system in the Romans testifies to the preference given to the logic of relations ${ }^{10}$.

It is noted that the forerunner of the change in the concept of property rights in the domestic legal system was the scientist of the Soviet period Y.G. Basin. He proposed to use the term "property right" as a generic term the statutory absolute right of the subject at his discretion and in his own interests to exercise full control over the immediate objects belonging to him. The scientist also identified the following types of property rights: property rights to things, ownership of substantive symbols of property benefits; ownership of current assets; intellectual property rights.

In other words, the concept of property can be considered necessary only if it does not suppress existing and emerging relationships, and is able to include all their variety. It remains, finally, the opportunity to proceed when determining ownership not from the subject area (which in fact determines the diversity of powers of the owner), but from the particular protection enjoyed by certain relationships. If absolute protection, resistance to

${ }^{8}$ Lazar J. Property in bourgeois legal theory: trans. from germ. / J. Lazar. M.: Law. Lit., 1985. $182 \mathrm{p}$.

${ }^{9}$ Shimon S.I. Property rights in the context of modern concepts of property rights in civilistics // Journal of the University of Law of Kiev. 2012/2. P. 192-195.

${ }^{10}$ Smirin V.M. Roman "familia" and the Romans' ideas about property // Life and history in antiquity. M., 1988, pp. 18-40. 
encroachment on the part of any third party can be considered primary, determining the property, then the objects of property will be all those objects that society desires and is able to protect in this way ${ }^{11}$.

\section{General provisions on the protection of property rights in ECtHR positions}

By its legal nature, property rights require regulation by the state, may be restricted, and the state is entitled to take certain measures of interference with property rights, including the deprivation of property. Herewith, the State must adhere to the established principles of lawful interference, in particular those elaborated by the European Court of Human Rights (hereinafter - ECHR), because of which decision the content of the provisions of the European Convention for the Protection of Human Rights and Fundamental Freedoms (hereinafter - the Convention) is understood., The First Protocol, their practical application.

The most favorable for the modern application of ECtHR Article 1 of Protocol 1 to the Convention is the concept of ownership in terms of the function's logic of defining property as the dominion of a thing, which is justified as far as the concept of limited real domination over real things is justified and also because this concept is the result of an inductive (in the sense that Cassirer put it) study ${ }^{12}$.

However, there is no need to understand a thing as a material unit (property). As Oswald Spengler remarked that in the current legislation (and since the time of O. Spengler - the second volume of "The Sunset of Europe" was published in April 1922 - the legislation in the field of property rights has practically not changed) "persons" and "things" in general are not concepts of law, but "only draw a banal boundary between man and everything else, they make, so to speak, a natural science distinction". From the above, O. Spengler concludes that if ancient law was the right of the body, then the modern law is the right of functions ${ }^{13}$.

The ECtHR's practice has a significant effect on the substantive content of the principles enshrined in the Convention for the Protection of Human

${ }^{11}$ Yakushev M.V. Voynykanys E.A. Information. Property. Internet. Tradition and short stories in modern law // Access mode: http://www.nnre.ru/kompyutery_i_internet/information_ sobstvennost_internet_tradicija_i_novelly_v_sovremennom_prave/index.php

${ }^{12}$ Yakushev M.V. Voynykanys E. A. Information. Property. Internet. Tradition and short stories in modern law // Access mode: http://www.nnre.ru/kompyutery_i_internet/information_ sobstvennost_internet_tradicija_i_novelly_v_sovremennom_prave/index.php

${ }^{13}$ Spengler O. The sunset of Europe. Essays on the morphology of world history. 2. World-historical perspectives / trans. from germ. and note. I.I. Makhankova. M .: Thought, 1998. -606 , P. 86. 
Rights and Fundamental Freedoms and its protocols. As a consequence, the established minimum legal standards are gradually being expanded and supplemented.

One of the first multilateral international treaties on the property rights' protection of certain categories of persons include the Hague Conventions of 1899 and 1907, which confirmed the principle of inviolability of private property during hostilities, which was formed as a customary rule of international law. The protection of property rights during hostilities was further developed in the provisions of the Geneva Conventions for the Protection of the Victims of War of 1949.

Thus, in the international legal context, the problem of the protection of property rights was initially considered exclusively in relation to foreigners, individuals and legal entities, since the regulation of relations between states and citizens regarding guarantees of protection of property rights was within the internal competence of states. With the development of international trade, happens an increase in the movement of persons, capital, services, goods (property) and related rights to it, making it necessary to regulate the protection of property rights at the international level as well.

Property right is fundamental, protected in accordance with the rules of national law, taking into account the principles of Article 1 of the First Protocol to the Convention for the Protection of Human Rights and Fundamental Freedoms. Particular protocols are included in the Convention, which supplement and develop its provisions. States Parties to the Convention are obliged to respect everyone's right to peaceful enjoyment of their possessions and to ensure that they are protected first and foremost at national level. This provision in Ukraine is enshrined at the constitutional level by the principle of inviolability of property rights (Article 41 of the Constitution of Ukraine).

The basic standards in the field of legal regulation of property relations include the Universal Declaration of Human Rights (1948) and the European Convention for the Protection of Human Rights and Fundamental Freedoms (1950), of which almost all European states, including Ukraine, are parties.

The function of ensuring a uniform interpretation and application of international agreements, compliance with international agreements on the part of States parties and on the part of organs of international organizations is entrusted to the judiciary, which are included in the structure of international organizations, European court of human rights (in the framework of the Council of Europe) and the European Court of justice (in the framework of the European Union). The European court of human rights is the judicial body explicitly mandated to solve disputes related to compliance with the European Convention for the protection of 
fundamental rights and freedoms of man and the European Court of justice decides the case on compliance of European Union law. Today, the judicial activity of the European court of human rights and the Court of the European Communities is one of the main guarantees of the effectiveness of European law and an important factor in its further development.

Article 17 of the Universal Declaration of Human Rights proclaims the property right as a fundamental and inalienable human right. The Convention for the Protection of Human Rights and Fundamental Freedoms is an international agreement, which establishes a list of the most important subjective human rights. To date, 45 countries have ratified this Convention. The Verkhovna Rada of Ukraine ratified it on July 17, 1997, and on September 11, 1997, it entered into force for our country. Now, under the jurisdiction of Ukraine, after all national remedies have been exhausted and within six months from the date of the final decision at the national level, not only is there a right, but also a real opportunity to apply to the European Court of Human Rights (France, m. Strasbourg) for the protection of their rights and freedoms as set out in the Convention and the Additional Protocols.

The term "exhaustion of national remedies" should be understood as referring the applicant to all the courts of the state, including the cassation instance - the Supreme Court. Thus, in the practical life introduced part 4 of Article 55 of the Constitution of Ukraine: "Everyone has the right, after the use of all domestic remedies, to apply for the protection of his rights and freedoms to the relevant international judicial institutions or to the relevant bodies of international organizations of which Ukraine is a member or party".

It is of great importance for the harmonization of the national legislation of the Parties to the Convention and European standards in the field of economic relations to consider the case law of the European Court of Justice (Article 1 of Protocol No. 1 to the Convention), since in most civil and economic disputes between physical or legal entities and the state being brought forward, ultimately, to the European Court of Justice, the issue of violation of property rights is raised.

Although there is no single clear doctrinal approach to defining what is property, there is still the ECHR, the case law of the European Court of Human Rights, there are EU regulations, the case law of the EU Court of Justice, which deals with a wide range of economic issues protected as 
provisions of Article 1 of the First Protocol and the provisions of Article 17 of the Charter of Fundamental Rights of the European Union ${ }^{14}$.

Thus, the ECtHR has repeatedly stated that the Convention is not a fixed legal act and is open to interpretation in the light of the needs of today. The object and purpose of the Convention as a legal act to protect human rights requires that its

rules be interpreted and applied in such a way as to make its safeguards effective and real ${ }^{15}$. Moreover, in modern science, this approach has been called "evolutionary interpretation"16.

Thus, Article 1 of Protocol No. 1 to the Convention defines the legal guarantees of property rights and regulates the substantive relations of property rights. In addition to this article, part of the property rights concerns article 6 of the Convention, which establishes guarantees of judicial protection, as well as article 13 of the Convention, which provides for the possibility of effective legal protection of violated rights.

Paragraph 1 of Article 17 of the Charter of Fundamental Rights of the European Union states that "Everyone has the right to own, use, dispose of and bequeath his lawfully acquired property. No one shall be deprived of his property, except in the interests of society and under the conditions provided for by law, provided that he is justly and timely compensated for the damage caused. Use of property may be regulated by law in accordance with the public interest"17.

In terms of the current judicial interpretation of the European Convention on the Protection of Human Rights and Fundamental Freedoms of 1950, the Institute of Property is the foundation of all private individual rights. The modernity of the view of international judges should be emphasized, since the legal regulation of private property relations is historically more ancient than the regulation of public-public relations. It is important to note that in the original text of the 1950 European Convention, there were no articles on the protection and respect of property rights. This is due to very different ideas about the concept of property and how it regulates States Parties.

Approaches to solving the problem were only clarified until 1952 in Protocol No. 1, which supplements the European Convention. Article 1 of

${ }^{14}$ Charter of Fundamental Rights of the European Union. European Union; Charter, International document dated 07.12.2000 // Access mode: http://zakon3.rada.gov.ua/laws/show/ 994_524

${ }^{15}$ V.A. Tumanov European Court of Human Rights: an outline of organization and activity / V.A. Tumanov. M.: Norm, 2001. - P. 90-91. 295 p.

${ }^{16}$ D.T. Karamanukian, Provocation of Crime in the Case Law of the European Court of Human Rights / D.T. Karamanukyan, Act. question publ. right. - 2013. - № 1. - P. 10-24.

${ }^{17}$ See ibid 
Protocol No. 1 guaranteed everyone the right to peacefully own their property and to defend their property rights. The term "property" is mentioned not in the text of the Convention for the Protection of Human Rights and Fundamental Freedoms, but in the text of Protocol No. 1 thereto. However, given that all protocols to the Convention are integral parts of the latter, the term "Convention" covers both the Convention itself and the Protocols thereto. Confirmation of this conclusion is contained, for example, in Art. 1 of the Regulation of the European Court of Human Rights, which states in paragraph (a) that the term "Convention" means the Convention for the Protection of Human Rights and Fundamental Freedoms and its Protocols.

According to P. Pushkar, regarding Art. 1 of the First Protocol to the Convention for the Protection of Human Rights and Fundamental Freedoms, the relevant provision is a norm of "constitutional" nature within the framework of EU law, part of the common property of the member states of the Council of Europe, part of the general principles of EU law, applied directly or through norms by EU states and institutions. Charter of Fundamental Rights of the European Union ${ }^{18}$.

An analysis of the case law of the European Court of Justice on the protection of property rights makes it possible to conclude that one of the problems is the correlation of national and pan-European property law when making court decisions.

The rulings of the European Court of Justice, in particular in the area of property relations, are a particular source of law and guide everyday practice for the legislative, judicial and other bodies of the member states of the Council of Europe, including in Ukraine. So, according to Art. 17 of the Law of Ukraine No. 3477-IV "On the Enforcement of Judgments and the Practice of the European Court of Human Rights" the ECtHR's practice is applied by the Ukrainian courts as a source of law. Therefore, it should be govern that the ECtHR, in examining cases under applications for the protection of the right to peaceful enjoyment of property, has worked out a number of generally recognized standards for the protection of this right, which boil down to such a general rule: when deciding whether a violation of Art. 1 of the First Protocol, it must be determined: whether the plaintiff owns the property covered by the content of Art. 1; whether there was an interference with the peaceful possession of the property and what is the nature of such interference; whether the deprivation of property occurred.

Judge scholars believe that since the ratification of the Convention and the First Protocol by Ukraine, the domestic judicial system has made

18 Ownership: European experience and Ukrainian realities: Proceedings of the International Conference (Kyiv, October 22-23, 2015). - K .: BAITE, 2015. - 324 p. P. 93. 
significant progress in applying the ECtHR's practice. It cannot be said that for all, however, for many judges, ECtHR decisions have ceased to be a "foreign body" in the legal system. Judges understand the ECtHR's findings and apply them to justify court decisions ${ }^{19}$.

Article 1 of Protocol No. 1 (1952) to the Convention provides: "Every natural or legal person is entitled to the peaceful enjoyment of his possessions. No one shall be deprived of his property except in the public interest and on the terms provided by law or by the general principles of international law".

The main purpose of Art. 1 of the First Protocol to the Convention is to prevent the arbitrary seizure of property, confiscation, expropriation and other violations of the principle of free use of their property, which are often or are likely to be practiced by the governments of States. And in this case, the principle of "inviolability of property rights" applies. The principle of "inviolability of property rights", according to P. Pushkar, can be considered as the main principle of legal regulation of property relations under EU law, in which particular attention is paid to the legality and proportionality (proportionality) of elements of interference with property rights as elements of assessing the legality of interference with property rights in general. In this regard, the case-law of the EU Court of Justice and the case-law of the European Court of Human Rights (for example, the case "Bosphorus Hava Jolari Tourism against Ministry of Transport of Ireland) concerning the right to conduct an airline's commercial activities (arrest of an airplane) under the existing UN embargo on FR Yugoslavia citing the decisionin the case "Sporrong and Lönnrotagainst Sweden") is indicative ${ }^{20}$.

The requirement of inviolability of property right implies compliance with the key principles of property protection, displayed in both EU law, ECHR and at the case law of the European Court of Human Rights: the lawfulness of interference with property relations, the proportionality of such interference, the review of actions or inaction of the State as a whole during the intervention in property relations, the principles of "fair balance" intervention, as well as the availability and adequacy of compensation, procedural protection and due legal guarantees pro that for such intervention (as well as the presence of guarantees).

Among all the rights guaranteed by the Convention for the Protection of Human Rights and Fundamental Freedoms, Art. 1 of Protocol No. 1 has a

19 Ownership: European experience and Ukrainian realities: Proceedings of the International Conference (Kyiv, October 22-23, 2015). - K .: BAITE, 2015. - 324 p. P. 7-23.

20 Ownership: European experience and Ukrainian realities: Proceedings of the International Conference (Kyiv, October 22-23, 2015). - K .: BAITE, 2015. - 324 p. P. 93 
special place, along with the guarantees of the right to a fair trial and the effective remedies provided for in Articles 6 and 13 of the Convention. This provision of the Convention is a distinguishing feature that makes the Convention a unique instrument among other similar international legal instruments, and, above all, the existence of this provision distinguishes the Convention from the International Covenant on Civil and Political Rights.

Analyzing Art. 1 of Protocol No. 1 to the Convention, it should be noted that this is the only article of the Convention and the Protocols thereto which, firstly, explicitly addresses the guarantees of the rights not only of individuals but also of legal person, and, secondly, concerns the issue property.

The basis of Art. 1 of the First Protocol to the Convention imposes twospecific decisions, "Marx v. Germany" and "Sporrong and Lonroth v. Sweden". The decision in the case of "Marx v. Germany" defined the purpose of Art. 1 of the First Protocol recognizes the right of any person to the free use of his property. The decision in the case of "Sporrong and Lonrothv. Sweden" identified the main requirements for the application of Art. 1 of the First Protocol on the Protection of Property Rights. As the Court found, the provisions of Art. 1 of the First Protocol provides for the following rules for the protection of property rights: the first norm, expressed in the first sentence of the first paragraph, is of a general nature and establishes the principle of unimpeded use of property, the second norm, expressed in the second sentence of the same paragraph, regulates cases of deprivation of property, setting certain conditions; in the third norm, expressed in the second paragraph, States Parties recognize the right to control the ownership of property in accordance with the common interest and the right to enforce the laws necessary to do so. Before finding out whether the first norm has been complied with, the Court must establish that the other two norms (Sporrong and Lönnrothv. Sweden) of 23 September 1982 are applicable in the present case NoNo 7151/75; 7152/75, Series A, No 52.).

However, as N.G. Gorobetsnotes, these principles are not separate from each other. The second and third rules "relate to specific cases of interference with the right to peaceful possession of property" and should be interpreted in the light of the general principle of the first sentence of Art. 1 of the First Protocol. Thus, the second and third rules relate to the three most important sovereign powers of the state, namely: the right to seize property in the public interest (eminent domain powers); rights to regulate the use of property (police powers); the right to set up a tax system ${ }^{21}$.

${ }^{21}$ Gorobets N.G. The concept and essence of property rights in the context of the First Protocol to the Convention for the protetonnes of Human Rights and Fundamental Freedoms 1950. and the European Court of Human Rights // Journal Kyiv University of Law • 2014/4 s. 307-312. 
The term "peaceful possession" in the context of Art. 1 of the First Protocol deserves attention. Violation of such "peaceful possession", which belongs to individuals and legal persons, is, in fact, any interference with the property rights of these persons. Such interference can take the form of deprivation of the opportunity to use the objects belonging to the property right to the specified persons, non-granting of the permits stipulated by the legislation, other forms of obstruction of the realization of the property right. As usually, the subjects of the last forms of interference with property rights are state bodies and officials. An analysis of the ECtHR's practice shows that the Court considers the protection of property rights precisely by interpreting the concept of "property". Herewith establishes a number of mandatory conditions that are necessary for the deprivation of property belonging to the respective persons on the property right ${ }^{22}$.

In Art. 1 of the First Protocol it is emphasized that "peaceful possession" means that a breach of the principle set out in the first sentence may also occur in the absence of direct or physical interference with the property right of a person. In their interpretation of the term "peaceful possession", the Commission and the Court often distinguish between "deprivation of property" and "control over its use". For example, a violation may take the form of deprivation of the opportunity to use property, failure to grant appropriate permits or other forms of impediment to the realization of property rights resulting from the application of legislation or measures by public authorities. Deprivation of property is the most serious restriction of ownership. This is, in fact, the subject of direct regulation of the second sentence of the first part of Art. 1 of the First Protocol, which requires that such deprivation occur in the public interest. According to a standard developed in the case-law of the Court, three criteria must be examined in order to determine whether a government measure complies with the requirements of this principle: whether the purpose of deprivation of property is "public interest"; whether the measure was in proportion to the stated objectives; whether such a measure was legitimate ${ }^{23}$.

The largest number of judgments of the European Court of Human Rights concerned the non-enforcement or prolonged non-enforcement of judgments of national courts concerning the protection of the possession of

${ }^{22}$ Kars-Frisc M. The right to property: the question of the implementation of Article 1 of the First Protocol to the European Convention on Human Rights / M. Kars-Frisco; in a row. AL Zhukovsky // European Convention on Human Rights: Basic Provisions, Application Practice, Ukrainian Context. - K., 2004. - P. 183.

${ }^{23}$ VP Kononenko, The Role of the Universal Declaration of Human Rights in the European Court of Justice's Interpretation of the 1950 Convention / VP Kononenko // Problems of Legality. - H., 2008. - Vyp. 99. P. - 206-220. 
their property. These categories of cases may be classified as substantive in the cases of: Piven' v. Ukraine, Zhovner v. Ukraine, Voitenko v. Ukraine, Shmalko v. Ukraine, Naumenko v. Ukraine, Dubenko v. Ukraine, Mikhailenko and others v. Ukraine, Derkach and Palek v. Ukraine, Sharenok v. Ukraine, Katsiuk v. Ukraine, etc. The number of such cases is increasing every year.

European Court comes from the fact that the establishment of the state of certain restrictions on the right to own property and useby the state measures to ensure to secure the payment of taxes should be considered as evidence of state interference in the peaceful enjoyment of property that is determined as one of the fundamental human rights. These facts should be analyzed on the reasonable using, that is legality, appropriateness and proportionality. As the analysis of the practice

shows, in this area the state tax authorities of Ukraine are often suspected of violating both the norms of the law and the general principles of law.

The third principle laid down in Art. 1, concerns not the deprivation of property but the sovereign powers of the state to regulate property relations. Despite of the Court's rather restrained approach to determining the compatibility of national property relations measures, which was inherent in the early years of the Convention's institutions, the Court's case-law further developed a more rigid standard for dealing with cases under Art. 1. As with most other provisions of the Convention, Art. 1 of the First Protocol may require the State to take appropriate affirmative action to ensure respect for property rights, even in relations between individuals and the like.

The obligation of the state to take measures to protect the rights guaranteed by the Convention (as opposed to the obligation to abstain from violating them) is referred to in the ECtHR as a "positive obligation".

The concept of positive obligations of the state is associated with Art. 1 of the Convention, which enshrines the obligations of the High Contracting Parties to respect human rights: "The obligation to protect the right to life contained in this rule (Article 2) shall be considered in conjunction with the general obligation of States under Article 1 of the Convention., "To provide for everyone within their jurisdiction the rights and freedoms set forth in Title I of this Convention".

Article 1 of Protocol No. 1 does not impose on the State an obligation to protect the property of citizens against encroachments on the part of individuals. This protection is indirectly exercised through the guarantees of Article 6 (right to a fair trial), which oblige the State to observe the procedural guarantees of the parties and to ensure the effective enforcement of judgments.

It is the duty of the State to interfere in civil-law relations between individuals in situations where one party to the agreement (especially the 
average citizen) puts by the law in obviously unequal conditions with respect to other parties to the agreement acting directly or indirectly in the interests of the state. In this case, the state should create such conditions in which the participants should be informed of the negative consequences of their actions (inaction) and can make decisions based on this information.

In establishing that there is a positive State obligation for a particular Convention law, the Court shall ensure that a fair balance is struck between the general interests of the public and the interests of the individual, the search for such a balance is inherent in the entire Convention. In doing so, it is guided by common positions, resolving specific cases: positive obligations cannot impose too heavy burden on the state in the course of their implementation or compliance, they are also narrowly worded as far as possible and should relate to fundamental conventional values.

The positive duties of the State are to take certain measures to ensure that individuals enjoy their rights; these measures should also aim at preventing the enjoyment of these rights by other individuals (the classical theory of D. Mill) and, conversely, by preventing the use of these rights by individuals.

In determining the positive obligations of a State in the application of certain articles of the Convention, their content and scope is significantly changed by the very fact of recognition of these responsibilities of those obligations. The Court has not, to date, formulated any coherent theory of positive obligations, and it is necessary to refer to the practice of applying separate articles of the Convention to analyze their content.

According to the researchers, the boundaries between the positive and negative obligations of the State provided for in Article 1 of Protocol No. 1 are not clearly defined. Nevertheless, these two responsibilities require the same principles to be applied. And in the case when the case is analyzed through the prism of a positive duty of the state, and in the case of determining the legality of intervention of the state authority there is no significant difference in the applied criteria. The European Court of Human Rights pays considerable attention, in particular, to providing the State with the possibility of judicial protection of the infringed law, so that the State has obligations that envisage certain measures necessary to protect property rights and, in particular, an obligation to provide a judicial procedure which would contain the necessary procedural safeguards and, thus, allowed the national courts to resolve all possible disputes between individuals effectively and fairly. In other words, to ensure compliance with the principle of peaceful possession of property, the state must ensure that the right to a fair and public hearing within a reasonable time by an independent and impartial tribunal established by law, the need for which arises from a violation of the right to peaceful possession, is respected. 
In the absence of compliance with this requirement, the Court may find a violation of such a right ${ }^{24}$.

\section{CONCLUSIONS}

Thus, considering Art. 1 of the First Protocol to the Convention and the mechanism for its application, it is necessary to remember the 3 provisions which form the content of this article:

(I) The principle of peaceful possession of property;

(II) Deprivation of property;

(III) Control of use.

This article contains three separate norms. The first norm, of a general nature, proclaims the principle of peaceful possession of property; the second norm deals with cases of deprivation of property and subordinates it to certain conditions - it is contained in the second sentence of the first part. The third norm recognizes that States have the right, in particular, to control the use of property, in accordance with the common interest, by introducing laws which they consider necessary for the purpose; this provision is contained in part two ${ }^{25}$.

Otherwise, Article 1 of Protocol No. 1 has three main points:

1) respect for property rights ("Every natural and legal person has the right to peacefully own his property");

2) impossibility of deprivation of property ("No one may be deprived of his property except in the interests of society and under the conditions provided by law and the general principles of international law");

3 ) conditions of restriction of property right in the form of control of the State over its use ("The preceding provisions shall not detract from the right of the State to enforce such laws as it deems necessary to exercise control over the use of property in the general interest or to secure the payment of taxes or other fees or penalties").

\section{SUMMARY}

The article explores the general provisions on the protection of property rights in the case law of the European Court of Human Rights. In particular, the fundamental guarantee of the protection of property rights is the ability to apply to the European Court of Human Rights for the protection of

${ }^{24}$ DV Novikov Guarantees for the protection of property rights in the ECtHR practice // Civil, Business, Commercial and Labor Law European Perspectives No. 2, 2016 . P. 93-94.

${ }^{25}$ Karss - Frisc N. Right to property: the issue of implementation of Article 1 of the First Protocol to the European Convention on Human liters of Judah / V kn .: The European Convention on Human Rights: principal provisions, practice of application, Ukrainian context. K., 2004. - P. 686. 
infringed, unrecognized or contested rights. Attention is drawn to the peculiarities of the interpretation by the European Court of Human Rights of the rules of Article 1 of the First Protocol. The doctrinal definition of ownership is analyzed. The necessary conditions for the application of the principle of peaceful ownership of property have been determined.

\section{REFERENCES}

1. Civil and Commercial Law of Foreign States: a textbook: in 2 volumes / answer. ed. E.A.Vasiliev, A.S. Komarov. - 4th ed., reworked and add. - M.: International Relations, 2008. - Vol. 1. - P. 560 p.

2. Convention for the Protection of Human Rights and Fundamental Freedoms: International Document of November 04, 1950 // Official Journal of Ukraine. - 1998. - № 13. - Art. 270.

3. Vladimirsky-Budanov M.F. Review of the history of Russian law / M.F. Vladimirsky-Budanov. - 7th ed. - Petrograd, Kiev: N.Y. Oglobin, 1915. - 699 p. P. 507.

4. Public ownership: problems of theory and practice: monograph / ed. V.A. Ustimenko / NAS of Ukraine, Institute of Economic and Legal Research. - Chernihiv: Desna Polygraph, 2014. - 308 p. P. 7.

5. Savel'ev V.A. Legal concept of property in Ancient Rome and modernity / V.A. Savel'ev. - The Soviet state and law. - Moscow: Nauka, 1990. - No 8. - P. 135-140. - P. 139.

6. Lazar J. Property in bourgeois legal theory: trans. from germ. / J. Lazar. - M.: Law. Lit., 1985. - 182 p.

7. Shimon S.I. Property rights in the context of modern concepts of property rights in civilistics // Journal of the University of Law of Kiev 2012/2. P. 192-195.

8. Smirin V.M. Roman "familia" and the Romans" ideas about property // Life and history in antiquity. M., 1988, pp. 18-40.

9. Yakushev M.V. Voinikanis E.A. Information. Property. Internet. Tradition and novels in modern law // Access mode: http://www.nnre.ru/ kompyutery_i_internet/information_sobstvennost_internet_tradicija_i_novel ly_v_sovremennom_prave/index.php

10. Spengler O. Sunset of Europe. Essays on the morphology of world history. 2. World-historical perspectives / trans. from germ. and note. I.I. Makhankova. - M.: Thought, 1998. - P. 86.

11. Charter of Fundamental Rights of the European Union. European Union; Charter, International document dated 07.12.2000 // Access mode: http://zakon3.rada.gov.ua/laws/show/994_524

12. Ownership: European experience and Ukrainian realities: Proceedings of the International Conference (Kyiv, October 22-23, 2015). - 
K.: BAITE, 2015. - 324 p. P. 93; Gorobets N.G. The concept and essence of property rights in the context of the First Protocol to the 1950 Convention on the Protection of Human Rights and Fundamental Freedoms and the European Court of Human Rights / / Journal Kyiv University of Law • 2014/4, s. 307-312.

13. Kars-Frisc M. The right to property: the question of the implementation of Article 1 of Protocol No. 1 to the European Convention on Human Rights / M. Kars-Frisc; in a row. O.L.Zhukovsky // European Convention on Human Rights: Basic Provisions, Application Practice, Ukrainian Context. - K., 2004. - P. 183-686.

14. Kononenko V.P. The role of the Universal Declaration of Human Rights in the interpretation by the European Court of the 1950 Convention / V.P. Kononenko // Problems of legality. - H., 2008. - out. 99. P. 206-220.

15. Novikov D.V. Guarantees for the protection of property rights in the ECtHR practice // Civil, Business, Commercial and Labor Law European Perspectives No 2, 2016. P. 93-94.

\section{Information about the author:} Kizlova O. S., Doctor of Laws, Professor, Head of the Department of Civil and Business Law and Process, International Humanitarian University 33, Fontanska Road str., Odessa, 65009, Ukraine 